\title{
Environmental Impact of The Use of Some Eco-friendly Natural Fungicides to Resist Rust Disease in Wheat
}

\author{
Shreen S. Ahmed ${ }^{1}$, Gehan H. Abd El-Aziz ${ }^{1}$, Mohamed A. Abou-Zeid ${ }^{2 *}$, Ashraf H. Fahmy ${ }^{3}$ \\ ${ }^{1}$ Soils, Water and Environment Research Institute, ARC, Giza, Egypt \\ ${ }^{2}$ Wheat Diseases Research Department, Plant Pathology Resarch Institute, ARC, Giza, Egypt \\ ${ }^{3}$ Plant Genetic Transformation Department, Agricultural Genetic Engineering Research Institute, ARC, Giza, Egypt
}

\begin{abstract}
Leaf rust disease of wheat, caused by Puccinia triticina, is one of the most severe fungal diseases on wheat leaves and it causes severe yield losses in Egypt. The aim of this study is to investigate the effect of some eco-friendly materials like waste agriculture extracts in order to reduce uses of chemical fungicides and to maintain sustainable development. Three experiments were conducted in the Laboratory, Greenhouse and Field. Neem cake, orange peels and rice straw were used to obtain eco-friendly natural fungicides while Sumi- 8 was used as a chemical fungicide and as a control. Three species from wheat cultivars, T.S.S, Morocco and Misr1 were used. Eco-friendly natural fungicides were applied as soak, foliar and applied together at the same time. Greenhouse and field experiments data showed that all natural extracts inhibited spore germination. Maximum inhibition reached to $100 \%$ by using neem cake and rice straw extracts followed with orange peels extract. In field experiments data showed that wheat yield was the highest using neem extract as soak + foliar application. The increase in wheat yield reached to $41.3 \%$ compared to Sumi-8 fungicide as healthy control. Also the results showed an increase in the percentage of carbohydrates, proteins, and wheat gluten, which is one of the main characteristics of the wheat quality. In conclusion these extracts can be used instead of chemical fungicide to cost effective, use safe and non-polluting environment.

Keywords: Wheat rust, Agriculture wastes, Chemical pesticides, Eco-friendly natural fungicides.
\end{abstract}

\section{INTRODUCTION}

Leaf rust disease of wheat, caused by Puccinia triticina, is one of the most severe fungal diseases on wheat leaves. It causes severe yield losses that could reach 50\% in Egypt and reducing grain quality (AbdelHak et al., 1980 and Cloutier et al., 2007). Wheat leaf rust is a global fungal disease that can spread rapidly by wind (Huerta-Espino et al., 2011). Regular use of fungicide is hazardous for the soil and for humans as well. Eco-friendly materials like plant extracts have gained great attention as substitution ways to chemical fungicides, that effect directly on the plant pathogens or indirectly by increasing resistance in plants (Mishra and Raja, 1999). Thus, application of plant extracts in disease control is considered as eco-friendly, without any environmental pollution. Plant extracts have been used in disease management for long time as foliar spray in different crops under different environmental conditions (Khalse et al., 2017). Gurjar et al. (2012) stated that some plants have components which are toxic to pathogens when extracted from these plants and used on infected crops. Plants can synthesize aromatic secondary metabolites; these metabolites such phenols, flavonoids, quinones, coumarins and tannins. These compounds are called botanical pesticides components were they are very active against the plant pathogens (Das et al., 2010). Egypt produces huge amounts of agricultural solid wastes every year. The elimination of agricultural solid waste is one of the most pressing environmental problems currently facing Egypt (Hussein et al., 2010). Neem seed cake performs the dual function of both fertilizer and pesticide, acts as a soil enricher, reduces the growth of soil pest and bacteria, provides macro nutrients essential for plant growth, and helps to increase the yield of plants. In the long run, bio degradable and eco-friendly and excellent soil conditioner (Lokanadha et al., 2012). Orange constitutes about $60 \%$ of the total citrus world production. A large portion of this production is addressed to the industrial extraction of citrus juice which leads to huge amounts of residues, including peel and segment. Many studies have reported antioxidant and antibacterial effect of juice and edible parts of oranges of different origin and from different varieties (Farag et al., 2009). Rice is one of the principal food crops in the world. Large amount of rice straw residues are produced after harvest. A major portion of this residue is disposed by burning which cause environmental problems. Several allelochemicals belong to different classes of secondary metabolites detected in rice residues and root exudates. These include phenolics (Seal et al., 2004), flavones, diterpenes, steroids (Macias et al., 2006). The aim of this study is to investigate the effect of some ecofriendly materials like waste agriculture extracts in order to reduce the use of chemical fungicides and to maintain sustainable development.

\section{MATERIALS AND METHODS}

\section{Preparation of eco-friendly natural fungicides}

At Environmental Department, Soil, Water and Environment Research Institute, ARC, Three different natural fungicides were prepared according to the method described by Van-Acker et al. (2011) with some modification. The neem cake, orange peels and rice straw were air dried for several days and ground to a fine powder $(0.05 \mathrm{~mm}) .200 \mathrm{~g}$ powdered samples as a tea bag was extracted with $500 \mathrm{ml}$ of ethanol at $45^{\circ} \mathrm{C}$ by Soxhelt for $6 \mathrm{~h}$. The residue was re-extracted three times 
to complete extraction. All extracts were collected and evaporated to dryness at $60^{\circ} \mathrm{C}$ by a rotary evaporator and the residues were dissolved in $100 \mathrm{ml}$ of sterile distilled water. The prepared extract was diluted to $10 \%$ with sterile distilled water.

\section{Green house experiment}

Seedling stage experiment was conducted at greenhouse experiment at the Wheat Disease Research Department, Plant Pathology Research Institute to test the efficacy of using the previous three natural fungicides (neem cake, orange peels and rice straw) to reduce the growth of wheat-rusted fungus compared with control. The most susceptible wheat cultivars (T.S.S, Morocco and Misr 1) were used in this experiment. Three natural fungicides were applied as seed-soaking, foliar spraying and both together applications. The experiment was laid-out in complete randomize design with three replicat. Freshly collected urediospores of Puccinia triticina $f$. sp. tritici race (TTTCS) were kindly provided by Wheat Dis. Res. Dept., Pl. Pathol. Res. Inst., ARC (the virulent strain) was used as inoculum. Seven days old wheat seedlings time from inoculation to commencement of sporulation, incubation period (IP) was recorded according to Katsuya and Green (1967). Plants were kept under daily observation till $50 \%$ of the pustules were erupted to estimate the latent period (LP) according to Parlevliet (1975). Infection types and number of pustules $/ \mathrm{cm}^{2}$ were determined by the method reported by Stakman et al. (1962).

\section{Field experiments}

This experiment was conducted in two different locations at the same time, these locations are Giza Experimental Station of Genetic Engineering Research Institute, Agricultural Research Center, Giza Governorate, Egypt and Sids Experimental Station of Agricultural Research Center, Beni Suef Governorate, Egypt in successive growing season (2016-2017) to confirm the results of the Green House experiment to control the rusting of leaves using environmentally friendly, safe and non-polluting materials. Split-split plot design with three replicate was adopted in this respect. The main plots were represented by the tested of three wheat species (T.S.S, Morocco and Misr 1). Sub-plots were represented by the tested of soaking, foliar, and both together treatments applications. Sub-sub plots were represented by the tested of five treatments, neem cake extract, rice straw extract, orange peels extract, Sumi-8 fungicide (healthy control) and untreated plants (infected control). Neem cake, orange peels and rice straw extract were used as natural fungicides while Sumi-8 fungicide $(0.35 \mathrm{ml} / \mathrm{l})$ was used as chemical fungicide. Different grains of wheat (T.S.S, Morocco and Misr 1) were soaked in different natural fungicides individually at rate of $10 \%(\mathrm{w} / \mathrm{v})$ for $4 \mathrm{hr}$ before planting. All natural fungicides were separately sprayed one day before inoculation with uredospores. When leaf rust appeared on wheat crop in the field, natural fungicides were sprayed every 2 weeks until milking stage. Artificial inoculation was carried out in boating stage (70 days old) as mentioned by Large (1954). Plants dusted with urediospores talk mixture (1:20) using a baby cyclone (Tervet and Cassel, 1951). T.S.S, Morocco and Misr 1 wheat cultivars was sprayed with their mixture. The tested strains were sprayed before and after inoculation by 24 hours. Rust severity was recorded using modified Cobb's scale (Peterson et al., 1948) during the course of the disease cycle. Also, area under disease progress curve (AUDPC) was calculated using a simple formula adopted by Pandey et al. (1989) as follows;

$\mathrm{AUDPC}=\mathrm{D}\left[1 / 2\left(\mathrm{Y}_{1}+\mathrm{Y}_{\mathrm{k}}\right)+\left(\mathrm{Y}_{2}+\mathrm{Y}_{3}+\ldots \ldots \mathrm{Y}_{\mathrm{k}-1}\right)\right]$

Where; $\mathrm{D}=$ time intervals, $\mathrm{Y}_{1}+\mathrm{Y}_{\mathrm{k}}=$ sum of the first and last disease scores and $\mathrm{Y}_{2}+\mathrm{Y}_{3}+\mathrm{Y}_{\mathrm{k}-1}=$ sum of all in between disease scores.

Physical and chemical characteristics of the studied soil before planting are presented in table (1). Soil was fertilized with $\mathrm{N}, \mathrm{P}$ and $\mathrm{K}$ with recommended rates.

Table (1): Properties of soils under study.

\begin{tabular}{lll}
\hline \hline Parameter & Giza Res. station & Sids Res. station \\
\hline sand \% & 27.5 & 17 \\
Silt \% & 38.0 & 37 \\
Clay \% & 34.5 & 46 \\
Soil texture & loamy clay & Clay loam \\
pH (1: 2.5, soil & 7.76 & 7.79 \\
Organic matter (\%) & 1.14 & 1.12 \\
ECe dS m-1, soil paste & 1.65 & 1.05 \\
Soluble cations (me/L) & & \\
Ca $^{++}$ & 6.8 & 3.50 \\
Na $^{+}$ & 3.4 & 1.55 \\
Mg $^{++}$ & 4.8 & 3.40 \\
$\mathbf{K}^{+}$ & 1.5 & 1.65 \\
Soluble anions (me/L) $_{\mathbf{C O}_{3}^{--}}$ & & \\
$\mathbf{H C O}^{-}$ & - & - \\
Cl $^{-}$ & 3.8 & 3.16 \\
SO$_{4}^{--}$ & 6.7 & 3.25 \\
\hline \hline
\end{tabular}

\section{Phytochemical test of natural fungicides}

Phytochemical studies of natural fungicides are presented in table (2). Phytochemical screening for alkaloids, steroids, triterpenoids, glycosides, carbohydrates, flavonoids, tannins, phlobatannins, antiquinones and saponins were carried out as described by Sofowora, 1993; Harborne, 1973; and Ogbuewu, 2008.

Table (2): Phytochemical analysis of natural fungicides

\begin{tabular}{lccc}
\hline \hline Phytochemical tested & Neem cake & Orange peels & Rice straw \\
\hline Terpenoids & + & - & + \\
Flavonoids & ++ & + & + \\
Tannins & ++ & - & + \\
Alkaloids & ++ & + & + \\
Steroids & ++ & +++ & + \\
Glycosides & + & + & ++ \\
Saponins & ++ & + & - \\
Antiquinones & + & + & + \\
Phlobatannis & + & - & + \\
\hline \hline
\end{tabular}

\section{Analytical methods}

Physical and chemical characteristics of the studied soil were determined according to Page et al. (1982). In plant sample, total chlorophyll content was calculated according to Arnon (1949). Total nitrogen was determined by micro-Kjeldahl method according to AOAC. (1990). Total carbohydrate was extracted according to Smith, et al. (1964) and determined using 
spectrophotometer according to Murphy (1958). Gluten content was determined by employing the procedure of Paul (2000). Total phenolics were determined by the method of Singleton and Rossi (1965). Total flavonoids content was measured by the aluminum chloride colorimetric assay according to Lee and Ismail (2012). Determination of Sumi-8 fungicide in soil samples leaves and grains of wheat plant were analyzed using High Performance Liquid Chromatography (HPLC) using a C18 reverse phase column, and UV detection at $280 \mathrm{~nm}$. At the end of season all plants were harvested and collected per plot and yield per feddan was calculated.

\section{Statistical Analysis}

All data were statistically analyzed using Mstatc computer program to calculate ANOVA and post-hoc Duncan's multiple range test for mean comparison, according to procedures outlined by Freed and Scott (1986).

\section{RESULTS}

\section{Effect of natural fungicides on leaf rust severity of seedling wheat}

The effectiveness of using different natural fungicides on components of wheat leaf rust disease caused by P.triticinia f.sp. tritici was evaluated under greenhouse are presented in tables (3 and 4). Foliar spraying of wheat seedlings and seed soaking experiments (4 hour before cultivation) were carried out under greenhouse conditions. Data in table (3) indicated that, all studied natural fungicides led to significant increase in incubation period when foliar sprayed onto wheat seedlings. This might be due to that natural fungicides induce systemic resistance as the main mechanism of activity on a plant (Urszula et al., 2004 and Ramamoorthy et al., 2001).

The best result was obtained when wheat seedlings of cultivar Misr 1 was soaked with orange peels extract where the incubation period was increased from 8 days (in control plants) to 10.30 days, also soaking wheat Misr 1 with neem cake extract the incubation period was increased from 7 days (in control plants) to 10 days. This effect might be due to neem extract has different types of components that control diseases (Singh et al., 2010a and Wang et al., 2010). Data in table (3) revealed that, the most prolonged latent period (12.61 days) was obtained by foliar spraying wheat seedlings with rice straw (24 hour after inoculation), compared with control treatments (10 days). This might be due to that rice straw extract has several methods to control the disease such as production of antifungal compounds including siderophre production, nutrient competition and the induction of systemic resistance (Chen et al., 1995; Ramamoorthy et al., 2001 and Urszula et al., 2004). It is important to note that, the natural fungicides caused a significant decrease in no. of pustules/leaf compared with control treatments (Table 4).

The significant reduction in no. of pustules/leaf was obtained by spraying seedlings with neem, rice straw and orange peels extracts, no. of pustules/leaf reached to $0,1.2$ and 2.2, respectively, at 24 hour after inoculation treatment. This high potentiality in antagonism might be due to that three natural fungicides acts through different mechanisms including production of antifungal substances, induction of systemic resistance in the plant and stimulate the plant to form phytoalexin (Ramamoorthy et al., 2001 and Urszula et al., 2004).

Table (3): Effect of soak and foliar wheat seedlings with different natural fungicide with Puccinia triticina on the incubation period and latent period under greenhouse experiment.

\begin{tabular}{|c|c|c|c|c|c|c|c|c|c|}
\hline \multirow{2}{*}{ Treatment } & \multirow{2}{*}{ Wheat species } & \multicolumn{4}{|c|}{ Incubation period } & \multicolumn{4}{|c|}{ latent period } \\
\hline & & Control & Soak & Foliar & Soak + Foliar & Control & Soak & Foliar & Soak + Foliar \\
\hline \multirow{3}{*}{ Neem extract } & T.S.S & 7 & 9 & 9 & 10 & 10 & 11.30 & 11.20 & 11.90 \\
\hline & Morocco & 7 & 8 & 9 & 10 & 10 & 10.5 & 11.34 & 11.20 \\
\hline & Misr 1 & 7 & 10 & 9 & 11 & 10 & 11 & 11.56 & 11.30 \\
\hline \multirow{3}{*}{ Rice straw extract } & T.S.S & 7 & 9 & 9 & 10 & 10 & 10.9 & 11.81 & 11.23 \\
\hline & Morocco & 7 & 9 & 9 & 10 & 10 & 10.91 & 10.80 & 11.5 \\
\hline & Misr 1 & 8 & 10 & 9 & 10 & 10 & 11.1 & 12.61 & 10.86 \\
\hline \multirow{3}{*}{ Orange peels extract } & T.S.S & 7 & 8 & 9 & 11 & 10 & 10.89 & 11.73 & 11 \\
\hline & Morocco & 7 & 8 & 9 & 10.30 & 10 & 10.45 & 11.34 & 11.2 \\
\hline & Misr 1 & 8 & 10.30 & 9 & 11 & 10 & 11.02 & 12.54 & 11.1 \\
\hline Mean & & 7.22 & 9.03 & 9 & 10.36 & 10 & 10.89 & 11.65 & 11.25 \\
\hline
\end{tabular}

Table (4): Effect of soak and foliar wheat seedlings with different natural fungicides, with Puccinia triticina on the no. of pustules/leaf and infection type under greenhouse experiment.

\begin{tabular}{|c|c|c|c|c|c|c|c|c|c|}
\hline \multirow{2}{*}{ Treatment } & \multirow{2}{*}{$\begin{array}{l}\text { Wheat } \\
\text { species }\end{array}$} & \multicolumn{4}{|c|}{ No. of pustules/leaf } & \multicolumn{4}{|c|}{ Infection type } \\
\hline & & Control (infected) & Soak & Foliar & Soak + Foliar & Control (infected) & Soak & foliar & Soak + Foliar \\
\hline \multirow{3}{*}{ Neem extract } & T.S.S & 75.39 & 22 & 4.4 & 1.2 & 4 & 2 & 1 & 0 \\
\hline & Morocco & 80 & 16.3 & 11.3 & 3 & 4 & 3 & 2 & 1 \\
\hline & Misr 1 & 54 & 2.3 & 0 & 0 & 3 & 0 & 0 & 0 \\
\hline \multirow{3}{*}{$\begin{array}{l}\text { Rice straw } \\
\text { extract }\end{array}$} & T.S.S & 75.22 & 19 & 8.4 & 4.9 & 3 & 2 & 1 & 0 \\
\hline & Morocco & 78 & 12 & 12.4 & 10.3 & 4 & 3 & 2 & 1 \\
\hline & Misr 1 & 56 & 4.2 & 1.2 & 0.85 & 4 & 0 & 0 & 0 \\
\hline \multirow{3}{*}{$\begin{array}{l}\text { Orange peels } \\
\text { extract }\end{array}$} & T.S.S & 76.33 & 20.1 & 5.4 & 3.8 & 3 & 2 & 1 & 1 \\
\hline & Morocco & 81.22 & 24.3 & 11.2 & 9.8 & 4 & 3 & $2^{+}$ & 0 \\
\hline & Misr 1 & 52 & 2.7 & 2.2 & 1.1 & 3 & 0 & 0 & 0 \\
\hline Mean & & 69.79 & 13.65 & 6.27 & 4.88 & 3.55 & 1.66 & 0.7 & 0.6 \\
\hline
\end{tabular}




\section{Environmental Impact of The Use of Natural Fungicides to Resist Rust Disease}

The inhibition effect of three extracts in reducing disease components extended to the significant reduction in infection type, compared with control. Data in tables (5 and 6) represent the effect of natural fungicides application on one successive growing season at Giza and Sids Research Sation (2016-2017), under field conditions. Data in such tables showed that, all treatments reduced rust severity. Application of extracts of neem, rice straw and orange peels at all studied periods, led to the lowest rust severity, compared with the control. Data also indicated that AUDPC was reduced in all treatments, compared with control. These results might be due to several mechanisms of bioagents known on plant pathogen including production of antifungal compounds such as siderophores production, nutrient competition and the induction of systemic resistance (Ferreira et al., 1991; Chen et al., 1995; Pieterse et al., 2001; Ramamoorthy et al., 2001 and Urszula et al., 2004).

Table (5): Effect of natural fungicides application on pathogen inoculation, on rust severity and area under disease progress curve (AUDPC), under field conditions at Giza Research Station

\begin{tabular}{|c|c|c|c|c|c|c|c|c|c|c|c|}
\hline \multirow{2}{*}{ Treatment } & \multirow{2}{*}{$\begin{array}{l}\text { Wheat } \\
\text { species }\end{array}$} & \multicolumn{5}{|c|}{ Final rust severity } & \multicolumn{5}{|c|}{ AUDPC } \\
\hline & & Control (infected) & Control (healthy) & Soak & Foliar & Foliar + Soak & Control (infected) & Control (healthy) & Soak & Foliar & Foliar + Soak \\
\hline \multirow{3}{*}{ Neem extract } & T.S.S & 60 & 10 & 20 & 25 & 10 & 770.00 & 70.00 & 227.50 & 315.00 & 192.50 \\
\hline & Morocco & 70 & 10 & 30 & 30 & 30 & 770.00 & 70.00 & 315.00 & 280.00 & 280.00 \\
\hline & Misr 1 & 30 & 0 & 10 & 5 & 0 & 203.00 & 0.00 & 70.00 & 17.5 & 0.00 \\
\hline \multirow{3}{*}{ Rice straw extract } & T.S.S & 80 & 10 & 20 & 40 & 20 & 1120.00 & 87.00 & 297.50 & 525.00 & 280.00 \\
\hline & Morocco & 70 & 10 & 30 & 50 & 40 & 682.50 & 88.00 & 227.50 & 542.50 & 507.50 \\
\hline & Misr 1 & 30 & 0 & 10 & 5 & 0 & 210.00 & 0.00 & 105.00 & 52.50 & 0.00 \\
\hline \multirow{3}{*}{ Orange peels extract } & T.S.S & 80 & 10 & 30 & 30 & 30 & 1015.00 & 70.00 & 490.00 & 420.00 & 490.00 \\
\hline & Morocco & 70 & 5 & 50 & 50 & 40 & 910.00 & 18.00 & 542.50 & 472.50 & 507.50 \\
\hline & Misr 1 & 10 & 5 & 10 & 5 & 10 & 105.00 & 15.50 & 70.00 & 52.50 & 70.00 \\
\hline Mean & & 55.56 & 6.67 & 23.33 & 26.67 & 20.00 & 642.83 & 46.50 & 260.56 & 297.50 & 258.61 \\
\hline
\end{tabular}

Table (6): Effect of bioagent application on pathogen inoculation, on rust severity and area under disease progress curve (AUDPC), under field conditions for 2016-2017 growing season at Sids Research Station.

\begin{tabular}{|c|c|c|c|c|c|c|c|c|c|c|c|}
\hline \multirow[b]{2}{*}{ Treatment } & \multirow[b]{2}{*}{$\begin{array}{l}\text { Wheat } \\
\text { species }\end{array}$} & \multicolumn{5}{|c|}{ Final Rust severity } & \multicolumn{5}{|c|}{ AUDPC } \\
\hline & & $\begin{array}{c}\begin{array}{c}\text { Control } \\
\text { (infected) }\end{array} \\
\end{array}$ & Control (healthy) & Soak & Foliar & Foliar + Soak & $\begin{array}{c}\text { Control } \\
\text { (infected) }\end{array}$ & Control (healthy) & Soak & Foliar & Foliar + Soak \\
\hline \multirow{4}{*}{ Neem extract } & T.S.S & 70 & 10 & 30 & 20 & 10 & 870.00 & 80.00 & 324.20 & 286.00 & 183.22 \\
\hline & Morocco & 70 & 10 & 25 & 30 & 10 & 740.00 & 78.00 & 310.00 & 280.00 & 170.00 \\
\hline & Misr 1 & 30 & 0 & 10 & 5 & 0 & 200.00 & 0.00 & 65.00 & 22.00 & 0.00 \\
\hline & T.S.S & 80 & 10 & 20 & 20 & 30 & 1110.00 & 92.00 & 280.50 & 370.00 & 310.00 \\
\hline \multirow{3}{*}{ Rice straw extract } & Morocco & 70 & 10 & 30 & 20 & 20 & 645.00 & 92.00 & 237.00 & 342.50 & 236.00 \\
\hline & Misr 1 & 30 & 0 & 10 & 5 & 0 & 250.00 & 0.00 & 110.00 & 73.50 & 0.00 \\
\hline & T.S.S & 80 & 10 & 30 & 20 & 25 & 1098.00 & 78.00 & 490.00 & 340.00 & 480.00 \\
\hline \multirow[t]{2}{*}{ Orange peels extract } & Morocco & 60 & 5 & 40 & 20 & 25 & 880.00 & 17.50 & 470.50 & 320.00 & 395.50 \\
\hline & Misr 1 & 20 & 5 & 10 & 5 & 5 & 154.50 & 17.50 & 82.00 & 64.00 & 60.50 \\
\hline
\end{tabular}




\section{Ahmed et al.}

\section{Effect of natural fungicides on wheat yield}

Data pertaining to yield of grain wheat treated with synthetic and natural fungicides illustrated graphically in Figure 1. In general, the highest values of yield were recorded in treated plants with neem extract followed with rice straw extract then orange peels extract. It is worth mentioning that, the grain yield of wheat under natural fungicides treatment was a higher than synthetic fungicide. Grain yield using neem extract reached 31.4 and $69.1 \%$ that of healthy control and infected control (Fig. 1A). Concerning the different application of natural fungicide, grain yield using three application (soak, foliar and soak + foliar) was observed in the following increasing order: soak $<$ foliar $<$ foliar + soak (Fig. 1B). Regarding the different species (Misr 1, Meracco and TSS), the highest value of yield was recorded in Misr1 compared to other species (Fig. 1C). From the statical analysis the interaction effect between treatment and species (Fig. 1D) data showed that the greatest value of grain yield was recorded in Misr spices using orange extract $(36.3 \%)$ followed with using neem extract (35\%) compared to untreated control. Also, data showed that the highest value of grain yield was recorded in Meracco spices using neem extract (2.1-fold) compared to untreated control. In addition, results observed that the highest value of grain yield was recorded in T.S.S species using neem extract (1.8-fold) compared to untreated control (Fig. 1D). Concerning the interaction between treatment and application, data showed that the maximum value of grain yield was recorded using neem extract applied as soak with foliar followed with foliar.

In case of orange extract the highest value was recorded using soak with foliar application while the rice straw, the highest value was recorded at foliar and soak with foliar application (Fig. 1E). Regarding the interaction between treatment application and species, data showed that the maximum value of grain yield was recorded using neem extract applied as soak + foliar in Misr1 species followed by orange extract. Generally, all natural fungicides improved the grain yield of wheat under all application. Grain yield using different treatments was in the following increasing order: untreated control < sumi-8 fungicide < orange peels extract < rice straw extract < neem extract. Also, grain yield using different application was in the following increasing order: soak < foliar < soak + foliar. The highest yield of wheat might be attributed to chemicals elicitor's effect on physiological processes in plant such as ion uptake, cell elongation, cell division, enzymatic activation and protein synthesis (Wieser, 2007)

The present results were in harmony with those obtained by many researchers with many different natural extract as: Azardiachta indica, Artem-essia annua, Eucalyptus globulus; Ocimum sanctum and Rheum emodi (Joseph et al., 2008); neem cake (Singh et al., 2010 b); Azadirachta indica, Lawsonia inermis, Allium sativum, Murraya koenigii, Ocimum sanctum (Sowjanya and Manohara, 2012); garlic, onion and ginger (Chaudhary and Chaudhari, 2013) and Plectranthus tenuiflorus, Azadirachta indica, Clerodendrum inerme, Schinus terebinthifolius and Mirabilis jalapa (El-sharkawy and El-Sawy, 2015). Plant extracts are effective biocontrol agents against a wide range of plant pathogens.
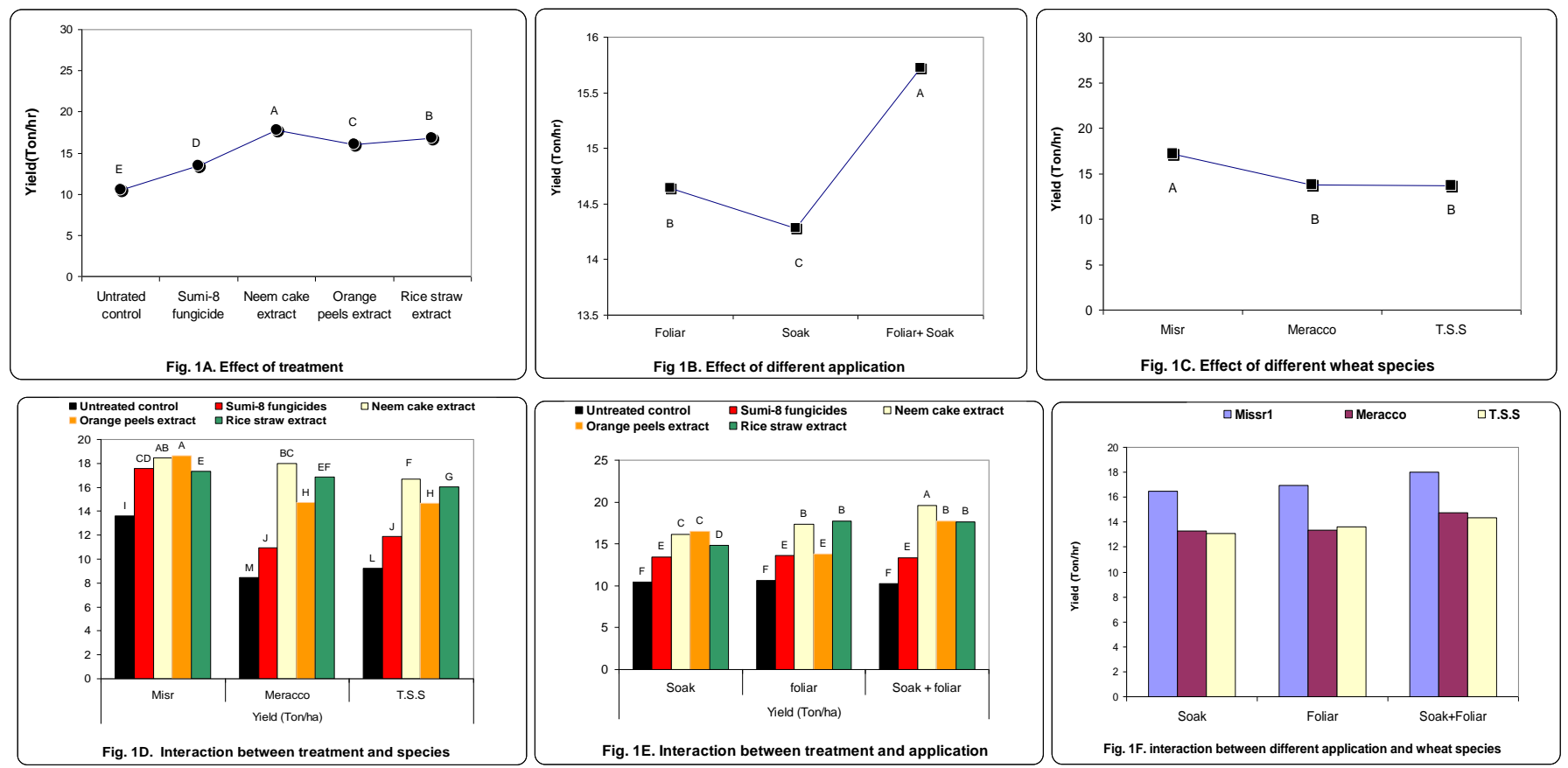

Figure (1): Effect of synthetic and natural fungicides on wheat yield. 


\section{Environmental Impact of The Use of Natural Fungicides to Resist Rust Disease}

\section{Effect of natural fungicides on chemical components of wheat grains}

Data pertaining to chemical components of wheat grains treated with synthetic and natural fungicides illustrated graphically in figure (2). The results showed that there was a significant increase in wheat grain content of total protein as well as gluten (Fig. 2A) of all treatments compared to control (infected). The increase percent of protein and glutein in Sumi-8 fungicide, neem extract, orange extract and rice straw extract treatments reached to 23,30, 26 and $28 \%$ for protein and $25,34,29$, and $32 \%$ for glutein, respectively. Data also showed that there was a decrease in total sugars content (Fig. 2B) of all treatments (Sumi-8 fungicide, neem extract, orange extract and rice straw extract) compared to control. The decease percent reached to $2.8,3.7,3.5$ and $3.6 \%$, respectively. The results showed that there was a significant increase in chlorophyll content (Fig. 2C) of all treatments compared to infected control. The increase percent reached to $76 \%$ for Sumi fungicide, $96 \%$ for neem extract, $87 \%$ for orange peels extract and rice straw extracts. Significant increase was observed in phenol and flavonoid content in wheat leaves for all treatments compared to infected control. Phenol using different treatments was in the following increasing order Sumi-8 fungicide $(24 \%)<$ orange peels extract $(61 \%)$ < rice straw extract $(75 \%)<$ neem extract $(80 \%)$. Flavonoids using differ- ent treatments were in the following increasing order: Sumi-8 fungicide $(33 \%)<$ orange peels extract $(56 \%)$ $<$ rice straw extract $(78 \%)<$ neem extract $(89 \%)$. Generally, under natural fungicides treatment there was an increase in chemical component of leaves and wheat grains. Biochemical metabolism changes due to fungal infection have been mentioned in different plants (Tamuli et al., 2013). Destruction of photosynthetic leaf area due to leaf disease development reduces the potential supply of photosynthate available for grain development and filling, leading to a reduction in barley grains yield as well as other yield components (Turkington et al., 2012). Plants have the ability to synthesize aromatic secondary metabolites, like phenols, phenolic acids, quinones, flavones, flavonoids, flavonols, tannins and coumarins (Cowan, 1999). These groups of compounds show antimicrobial effect and serve as plant defense mechanisms against pathogenic microorganisms (Das et al., 2010). Plants of Meliaceae family, especially neem, contain at least 35 biologically active compounds (Pennington and Styles, 1975) which are the most active insecticidal ingredients and are present predominantly in the seeds, leaves and other parts of the neem tree. The active ingredients of neem constitute mostly of triterpenoides (Brahmachari, 2004). The inhibitory effect of the plant extracts might be attributed to the presence of antifungal components (Joseph et al., 2008).
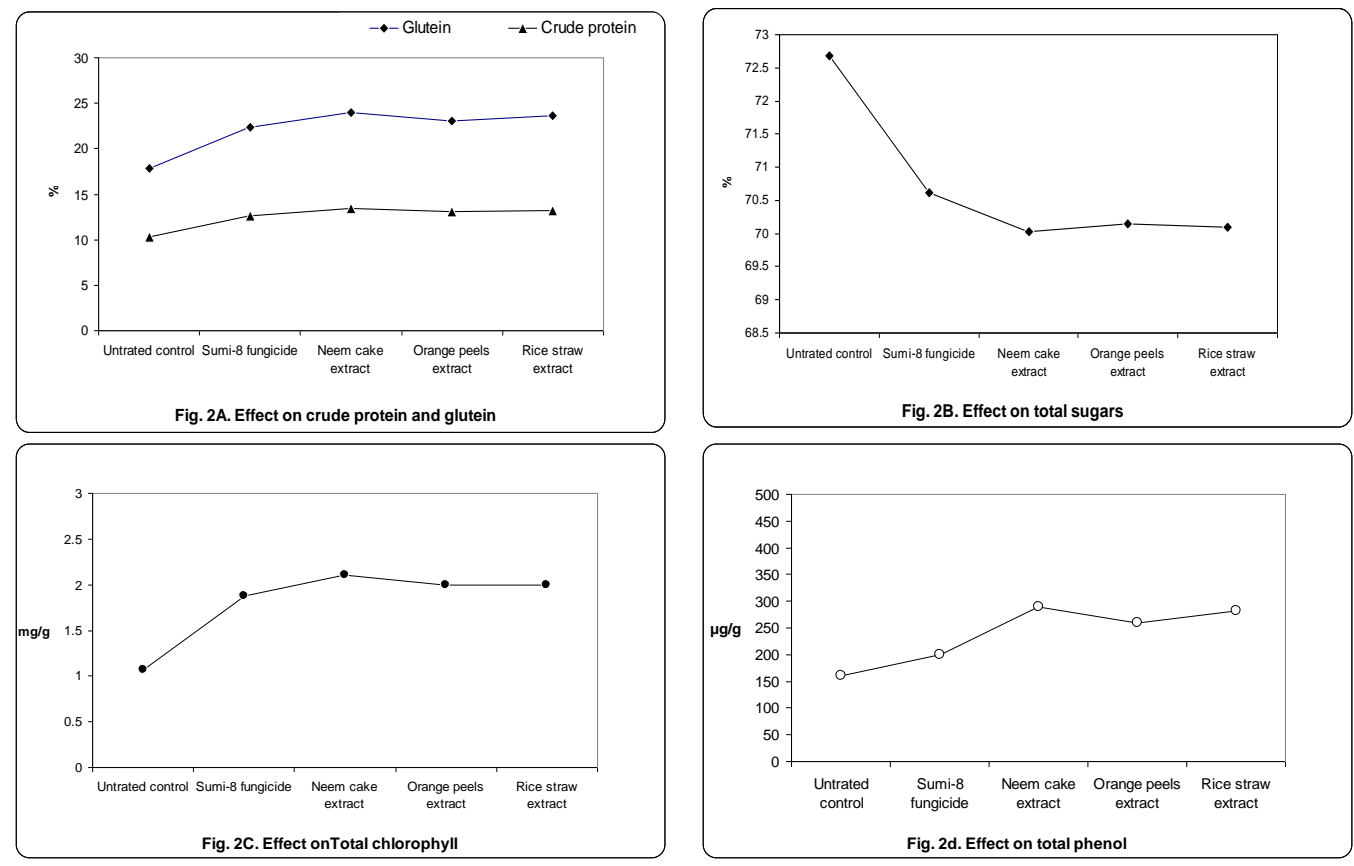

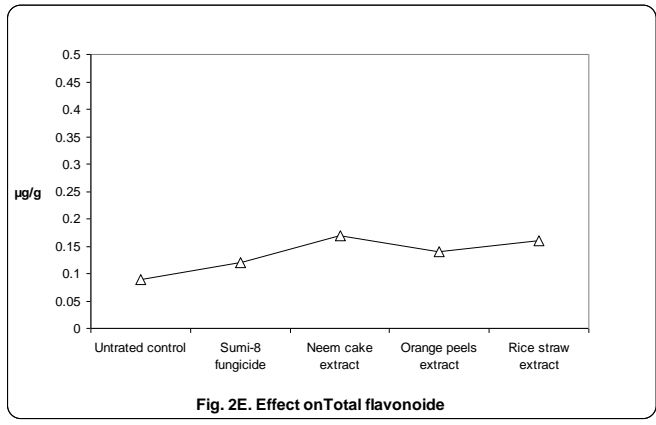

Figure (2): Effect of synthetic and natural fungicides on chemical components of wheat yield. 
Residual of Sumi-8 fungicide in soil, leaves and grains wheat

The residual of Sumi-8 fungicide in soil, leaves and grains of wheat are presented in figure. 3 . The obtained results showed that there is a residual effect due to the use of the fungicide on both soil and plant. Where, the residual of fungicide was detected in the soil and wheat leaves, the fungicide reached to 0.04 and $0.09 \mathrm{ng} / \mathrm{g}$, respectively. It worth mentioned that, traces of the fungicide were detected in grains of wheat. From an environmental point of view the presence of fungicide residues in agricultural soils may be undesirable to soil bacterial community due to the accumulation of Sumi8 fungicide molecule due to its adsorption on the soil matrix. Apply of plant extracts in disease control is considered as eco-friendly, non-polluting environment and sustainable approach for disease control. Furthermore, resistance development in pathogen against biocontrol agents has not been reported so far while frequent use of fungicides has led to resistance development in various pathogens. Bio-control agents have been used in disease control for long time as seed treatment but their use as foliar spray is rarely followed approach and needs screening in different crops and under different environmental conditions (Kumar and Mauriya, 2015).

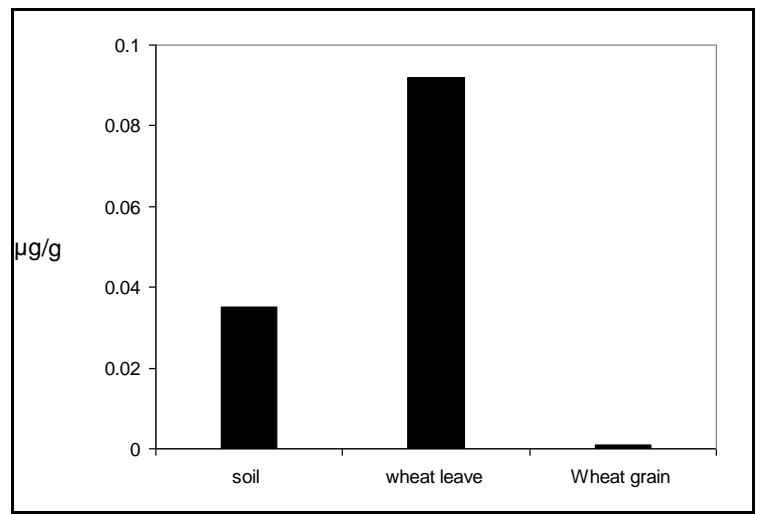

Figure (3): Residual of fungicide sumi- $8 \mathrm{~cm}$ soil and plant.

\section{Conclusion}

No doubt in the past few decades chemical pesticides have protected the plants from diseases, their continuous and over use have led to some serious ecological problems, viz. hazardous effects on beneficial organisms in soil, residual effects, pollution and resistant strain development in pathogen. Therefore, the results of this study can recommend the possibility of producing natural fungicides from the plant wastes, which showed a great ability to resist wheat rust disease as the results were close to the use of chemical pesticides. Furthermore, the effects of the use of natural fungicides have a positive effect on wheat yield and yield components compared to chemical fungicides.

\section{References}

ABDEL-HAK, T.M., N.A. EL-SHERIF, A.A. BASSIOUNY, I.I. SHAFIK, Y.H. EL-DAUADI.
1980. Control of wheat leaf rust by systemic fungicides. Proceedings of the Fifth European and Mediterranean Cereal Rusts Conference. Bari, Italy 255-266

AOAC. 1990. Association of Official Analytical Chemists. Official Methods of Analysis of the AOAC, 15th Edn., Washington, D.C.

ARNON, D.I., 1949. Copper Enzymes in Isolated Chloroplasts. Polyphenol Oxidase in Beta vulgaris. Plant Physiol; 24: 1- 15.

BRAHMACHARI, G., 2004. Neem an omnipotent plant: retrospection. Chembiochem; 5: 408-421.

CHAUDHARY, R.E., AND M.G. CHAUDHARI. 2013. Effect of fungicides and plant extracts on uredospores germination of Puccinia recondita $\mathrm{f}$. sp. tritici. Bioscan; 8: 59-62.

CHEN, C., E.M. BAUSKE, G. MUSSON, R. RODRIGUEZKABANA, AND J.W. KTOEPPER. 1995. Biological Control of Fusarium wilt on Cotton by Use Endophytic Bacteria. Biological Control; 5: 83-91.

CLOUTIER, S., B.D. MCCALLUM, C. LOUTRE, T.W. BANKS, T. WICKER, C. FEUILLET, B. KELLER, M.C. JORDAN. 2007. Leaf Rust Resistance Gene Lr1, Isolated from Bread Wheat (Triticum aestivum L.) is a Member of the Large psr567 Gene Family. Plant Mol. Biol; 65: 93-106.

COWAN, M.M. 1999. Plant products as antimicrobial agents. Clin Microbiol Rev ; 12:564-582.

DAS, K., R.K. TIWARI, AND D.K. SHRIVASTAVA. 2010. Techniques for Evaluation of Medicinal Plant Products as Antimicrobial Agent: Current Methods and Future Trends. J Med Plants Res; 4:104-11.

EL-SHARKAWY, M.M., AND M.M. EL-SAWY. 2015. Control of bean common mosaic virus by plant extracts in bean plants. Int. J. Pest. Manag.; 61 (1), 54-59.

FARAG, R.S., Z.Y. DAW, F.M. HEWEDI, AND G.S. EL-BAROTY. 2009. Antimicrobial Activity of some Egyptian Spice Essential Oils; J. Food Prot., 72: 665-667.

FERREIRA, J.H.S., F.W. MATTHEE, AND A.C. THOMAS. 1991. Biological Control of Eutypa lota on Grapevine by an Antagonistic Strain Bacillus subtilis: Phytopathology; 81: 283-287.

FREED, R.D., AND D.E. SCOTT. 1986. MSTATC. Crop and Soil Sci. Dept., Michigan State University Michigan, USA.

GURJAR, M.S., S. ALI, M. AKHTAR, AND K.S. SINGH. 2012. Efficacy of Plant Extracts in Plant Disease Management. Agric Science; 3: 425-33.

HARBORNE, J.B. 1973. Phytochemical Methods, a Guide to Modern Techniques of Plant Analysis $4^{\text {th }}$ ed. $1-5,182-191$.

HUERTA-ESPINO, J., R. SINGH, S. GERMÁN, B. MCCALLUM, R. PARK, W. CHEN, S. BHARDWAJ, H. GOYEAU. 2011. Global Status of Wheat Leaf Rust Caused by Puccinia triticina. Euphytica, 179: 143-160.

HUSSEIN, A., S. D.SAWAN, AND M. OMAIMA. 2010. The Uilization of Agricultural Waste as One of the Environmental Issues in Egypt (A Case 


\section{Environmental Impact of The Use of Natural Fungicides to Resist Rust Disease}

Study). Journal of Applied Sciences Research; 6: 1116-1124.

JOSEPH, B., M.A. DARAND, AND V. KUMAR. 2008. Bioefficacy of Plant Extracts to Control Fusarium solani F. Sp. melangenae Incitant of brinjal wilt. Glob J. Biotechnol. Biochem., 3: 5659.

KATSUYA, K., AND G.J. GREEN. 1967. ReproDuctive Potential of Races 15 B and 26 of Wheat Stem Rust. Can. J. Bot.; 45: 1077-1091.

KHALSE, D.K., A.L. ABHILASHA, AND S. SOBITA. 2017. Efficacy of Bio-agents and Plant Extracts Against the Alternaria leaf spot of cabbage (Alternaria brassicae). Journal of Pharmacognosy and Phytochemistry, 6(4): 1980-1982.

KUMAR, S., AND A. K. MAURIYA. 2015. Effect Of Fungicides And Plant Extracts For Management Of Management of Management of Turcicum Leaf Blight of Maize. International Quarterly Journal of Life Science. 10(4): 1687-1690.

LARGE, E.C. 1954. Growth Stages In Cereals. Illustration of the Feek's scale. Pl. Pathol., 3: 128129.

LEE, W.H., AND I.S. ISMAIL. 2012. Antioxidant activity, total phenolics and total flavonoids of Syzygium polyanthum (Wight) Walp leaves. Int J Med Arom Plants , 2(2): 219-228.

LOKANADHA, S.N, P. MUTHUKRISHNAN, AND S. JEYARAMAN. 2012. Neem Products and Their Agricultural Applications. J. Biopest, 5: 72-76.

MACIAS, F.A., N. CHINCHILLA, R.M. VARELA, AND J.M.G. MOLINILLO. 2006. Bioactive Steroids from Oryza sativa L. Steroids 71:603-608.

MISHRA, S.K., AND R. RAJA. 1999. Systemic Acquired Resistance: a review. Ann Agric Res; 20: 249-59.

MURPHY, R.P. 1958. Extraction of Plant Samples and the Determination of Total Soluble Carbohydrates. J. Sci. Food Agric., 9: 714-717.

OGBUEWU, I.P. 2008. Physiological Responses of Rabbits Fed Graded Levels of Neem (Azadirachta indica) Leaf Meal. M.Sc. Thesis, Federal University of Technology, Owerri.

PAGE, A.L., R.H. MILLER, AND D.R. KEENEY. 1982. Methods of Soil Analysis. II: Chemical and Microbiological Properties, $2^{\text {nd }}$ ed. Am. Soc. Agron. Inc; Soil. Soil Sci Soc. Am. Inc, Madison, Wisconsin U.S.A.

PANDEY, H.N., T.C.M. MENON, AND M.V. RAO. 1989. A Simple Formula for Calculating Area Under Dsease Progress Curve. Rachis, 8(2): 38-39.

PARLEVLIET, J.E. 1975. Partial Resistance of Barley to Leaf Rust, Puccinia hordei. I. Effect of Cultivars and Development Stage on Latent Period. Euphytica, 24:21-27.

PAUL, S.T. 2000. Approved Methods of the American Association of Cereal Chemists, 10th Edition.

PENNINGTON, T.D., AND B.T. STYLES. 1975. A Generic Monograph of the Meliaceae. Blumea; 22: 419-540.

PETERSON, R.F., A.B. CAMPBELL, AND A.E. HANNA. 1948. A diagrammatic Scale for Estima- ting Rust Intensity on Leaves and Stems of Cereals. Can. J. Res., 26:496-500.

PIETERSE, C., J. PELT, S. WEES, J. TON, K. KLOOSTERERZZIEL, J. KERURENTJES, B. VERHAGEN, M. KNOESTER, I. SLUIS, P. BAKKER, AND L. LOON. 2001. RhizobacteriaMediated Induced Systemic Resistance: Triggering, Signaling and Expression. Eur, J. Plant Pathology. 107: 51-61.

RAMAMOORTHY, V., R. VISWANATHAN, T. RAGUCHANDER, V. PKAKASAM, AND R. SAMIVAPPAN. 2001. Induction of Systemic Resistance by Plant Growth Promoting Rhizobacteria in Crop Plants Against Pests and Diseases in: Crop Protection. 20 (1): 1-11.

SEAL, A.N., J.E. PRATLEY, T. HAIG, AND M. AN. 2004. Identification and Quantification of Compounds in a Series of Allelopathic and Nonallelopathic rice root exudates. J. Chem. Ecol. 30:16471662.

SINGH, U.P., L. GOHAIN, A. SINGH, S. MAURYA AND S. SAHANI. 2010b. Phenolic Acid Change in Mycelia of Sclerotium rolfsii as Influenced by Neem Cake and Zephyarenthes citrine Bulb. Arch Phytopathol Plant Protect; 43:160-167.

SINGH, U.P., S. MAURYA, A. SINGH, AND L. GOHAIN. 2010a. Foliar Spray of Aqueous Extracts of Neem Cake to Control Balsam powdery Mildew. Arch Phytopathol Plant Protect; 43:1056-1063.

SINGLETON, V.L., AND J.A. ROSSI. 1965. Colorimetry a total phenolics with phosphomolibdic phosphotungstic acid reagents. Am. J. Enol. Vitric. 16, 144-158.

SMITH, D., G.M. PAULSEN, AND C.A. RAGUSE. 1964. Extraction of Total Available Carbohydrates From Grass and Legume Tissue. Plant Physiol., 39: 960-962.

SOFOWORA, A. 1993. Medicinal Plants and Traditional Medicine in African Spectrum Book Ltd. University of Ife Press Nigeria. Pp.119.

SOWJANYA, N., AND C. MANOHARA. 2012. Effect of Plant Extracts on The Growth of Microsorum gypseum. J Phytopathol; 4: 41-44.

STAKMAN, E.C., D.M. STEWART, AND W.Q. LOEDERING. 1962. Identification of Physiologic Races of Puccinia graminis f.sp. tritici. A.R.S. USA Agric. Res. Service. Bull., E, 617, p. 53.

TAMULI, P., M. SAIKIA, AND P. BORUAH. 2013. Post-Inflectional biochemical changes in Cymbopogon martinii (Roxb.) Wats and Cymbopogon citratus (DC) Stapf. Due to Leaf Rust Disease; American Journal of Plant Sciences, 4:1666-1668.

TERVET, I., AND R.C. CASSEL. 1951. The Use of Cyclone Separation in Race Identification of Cereal Rusts. Phytopathology, 41:282-285.

TURKINGTON, T.K., J.T. O'DONOVANL, M.J. EDNEY, P.E. JUSKIW, R.H. MCKENZIE, K.N. HARKER1, G.W. CLAYTON, K. XI, G.P. LAFOND, R.B. IRVINE, S. BRANDT, E.N. JOHNSON, W.E. MAY, AND E. SMITH. 2012. Effect of Crop Residue, Nitrogen Rate and Fungicide Application on Malting Barley Productivity, 


\section{Ahmed et al.}

Quality, and Foliar Disease Severity. Can. J. Plant Sci. 92: 577-588.

URSZULA, W., M. BARBARA, B. MONIKA, AND

K.K. ZOFIA. 2004. Biological Control of Winter Wheat Pathogens by Bacteria: Acta Fytotechnica Et Zootechnica. 7(1): 349-350.

VAN-ACKER, S.A., D.J. DEN, M.N. TROMP, AND

A. BAST. 2011. Structural Aspects of Antioxidant
Activity of Flavanoids. Free Radic. Biol. Med., 35: 331-342.

WANG, J., L.I. JIAN, J. CAO, AND W. JIANG. 2010. Antifungal Activities of Neem (Azadirachta indica) Seed Kernel Extracts on Postharvest Diseases in Fruits, African Journal of Microbiology Research; 4 (11): 1100-1104.

WIESER, H. 2007. Chemistry of Gluten Proteins. Food Microbiol 24: 115-119.

\section{التأثيرات البيئية لاستخدام بعض مبيدات الفطريات الطبيعية الصديقة للبيئة لمقاومة أمراض الصدأ في القمح}

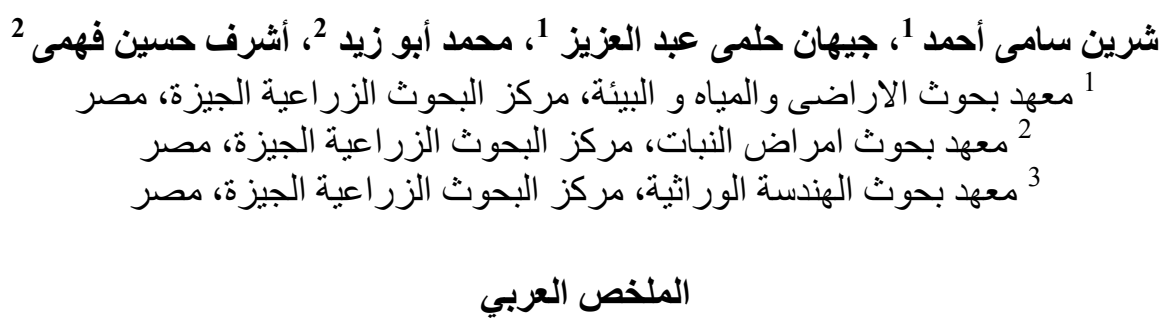

يعتبر مرض لصدأ القمح، الناتج عن فطر بكسينا ترتسينا أحد الأمراض الفطرية الأكثر ضررا على القمح ويسبب خسائر في محصول القمح المصرى. تهدف هذه الدراسة إلى در اسة تأثير بعض المو اد الصديقة للبيئة مثل مستخلصات المخلفات الزر اعية من

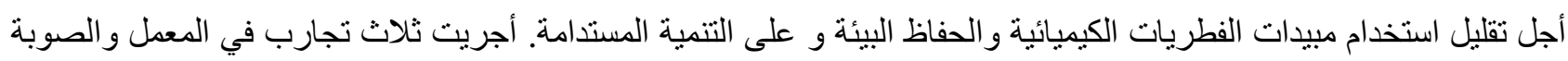
والحقل .تم استخدام كعكة النيم، قثور البرتقال وفش الأرز للحصول على مبيدات الفطريات الطبيعية الصديقة للبيئة في حين تم

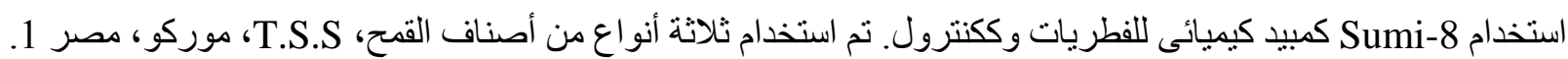
ونم تطبيق مبيدات الفطريات الطبيعية الصديقة للبيئة نقعا للحبوب، ورشا على الاور اق ونطبيقهما معا في نفس الوقت. و أظهرت نتائج التجربة الصوبة أن جميع المستخلصات الطبيعية تثبط إنبات الجراثيم. بلغ الحد الأقصى لتثبيط 100٪ باستخدام مستخلص كعكة النيم ثم مستخلص قش الأرز منبو عة بمستخلص قشور البرتقال. في التجارب الحقلية أظهرت النتائج أن محصول القمح كان

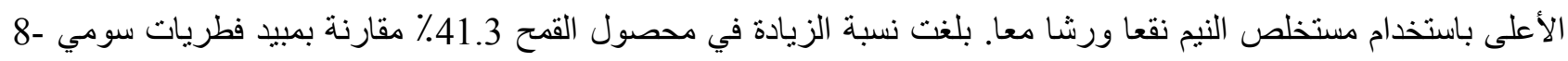
ككنترول. كما أظهرت النتائج زيادة في نسبة الكربو هيدرات و البروتينات وجلوتين القمح، و التي تعد واحدة من الخصائص الرئيسية لجودة القمح. وتوصى هذه الدراسة، انه يمكن استخدام هذه المستخلصات بدلاً من مبيد الفطريات الكيميائي كمبيدات فطرية طبيعية قليلة التكلفة و آمنة و غير ملوثة للبيئة. 